Rev. Int. Contam. Ambie. 37, 611-622, 2021

https://doi.org/10.20937/RICA.54083

\title{
TROPHIC STATUS OF A TROPICAL COASTAL LAGOON IN MARGARITA ISLAND, VENEZUELA
}

\author{
Estado trófico de una laguna costera tropical en la isla de Margarita, Venezuela
}

\author{
Carlos PEREIRA-IBARRA* and Fabiola LÓPEZ-MONROY
}

Escuela de Ciencias Aplicadas del Mar, Universidad de Oriente, Código Postal 6304, Boca del Río, Isla de Margarita, Venezuela.

*Author for correspondence: carlosjpereyra2@gmail.com

(Received: July, 2020; accepted: December, 2020)

Key words: eutrophication, Caribbean Sea, nutrients, Punta de Piedras, trophic index

\begin{abstract}
Punta de Piedras Lagoon is a coastal lagoon located south of Margarita Island, in the Venezuelan Caribbean Sea. This lagoon has ecological and economic importance for the inhabitants of nearby communities. Currently, the urban and industrial development in its surroundings represents a potential source of pollutants, providing concentrations of nutrients that could affect the ecological balance of the area. The trophic status of Punta de Piedras Lagoon was evaluated using various trophic indices. The concentrations of chlorophyll- $a$ and nutrients (ammonium, nitrites, nitrates, and orthophosphates) were estimated in 10 stations with a monthly frequency from February 2005 to January 2006. These data were used to estimate the trophic condition based on the Karydis and TRIX trophic indices, and by comparison with Organization for Economic Co-operation and Development reference values. It was found that Punta de Piedras lagoon presented mesotrophic conditions in most of the water body having considerable differences between indices. The values of the closest station to Paseo Esther Gil corresponded to eutrophic waters. However, the circulation and residence time of water allow an exchange with the adjacent sea, which prevents the eutrophication process in the lagoon.
\end{abstract}

Palabras clave: eutrofización, índice trófico, mar Caribe, nutrientes, Punta de Piedras

\section{RESUMEN}

La Laguna de Punta de Piedras es una laguna costera situada al sur de la isla de Margarita, en el mar Caribe venezolano, que tiene importancia ecológica y económica para la zona. En la actualidad el desarrollo urbano e industrial en sus alrededores son fuentes potenciales de contaminantes y aportan concentraciones de nutrientes que pudieran afectar el equilibrio ecológico de la zona. Se realizó la evaluación del estado trófico de la Laguna de Punta de Piedras usando varios índices tróficos. Se estimaron las concentraciones de clorofila $a$ y los nutrientes amonio, nitritos, nitratos y ortofosfatos en 10 estaciones, con una frecuencia mensual de febrero 2005 a enero 2006. Estos datos fueron empleados para estimar la condición trófica a partir de los índices de eutrofización de Karydis y TRIX y por comparación con valores referenciales de la Organización para la Cooperación y el Desarrollo Económicos. Se obtuvo que la laguna 
tiene una condición mesotrófica en la mayor parte del cuerpo de agua con diferencias apreciables entre los índices utilizados. La estación más cercana a Paseo Esther Gil presentó valores que corresponden a aguas eutróficas. Sin embargo, la circulación y el tiempo de residencia del agua facilitan un intercambio con el mar adyacente, lo cual evita que ocurra un proceso de eutrofización en la laguna.

\section{INTRODUCTION}

Coastal lagoons are shallow brackish, marine, or hypersaline water bodies, separated from the ocean by a sand barrier. They are intermittently or permanently connected to the sea. This configuration produces an ecological, hydrological, and sedimentological gradient that forms a complex mosaic of different habitats (Kennish and Paerl 2010, Cataudella et al. 2015, Pérez-Rufaza et al. 2020). Coastal lagoons occupy about $13 \%$ of coastal areas worldwide, distributed in all continents except Antarctica, making them a relevant component of coastal landscapes (Kennish and Paerl 2010). Additionally, they are highly productive systems, albeit sensitive, which provide refuge and breeding areas for multiple species, including many thar are threatened (Pérez-Rufaza et al. 2011, Potts et al. 2014). These characteristics offer favorable environments for the development of human activities such as fishing, aquaculture, transport, electricity generation, tourism, and even spiritual and cultural endeavors. However, these activities could threaten their structure and functioning due to their sensitivity (Kennish and Paerl 2010, Pérez-Rufaza et al. 2011, Cataudella et al. 2015, Béjaoui et al. 2018).

One of the main threats to coastal lagoons is the excessive enrichment of nutrients as a consequence of the continuous contributions of agricultural, industrial, and urban activities, which have intensified in recent years (Fisher et al. 2010, AnguianoCuevas et al. 2015, Le Fur et al. 2019). Nutrients determine primary productivity of the system and its dynamic is governed by multiple interactions of physical, chemical, and biological processes, which vary in time and space (Cloern 1999, Lee and Arega 1999, Boesch 2002, Kennish and Paerl 2010). For example, nutrient shortages are associated with a trophic state of oligotrophy, which corresponds to environments with minimal primary production, while nutrient overload causes eutrophication (Contreras et al. 1995, Nixon 1995, Cloern 2001, Pérez-Rufaza et al. 2020).

Eutrophication is a complex phenomenon in which the continuous and massive generation of biomass, mainly phytoplankton, promotes serious problems in energy flows (Livingston 2000, Kennish and Paerl 2010, Cutrim et al. 2019). This phenomenon manifests with high levels of chlorophyll- $a$ due to the accelerated growth of algae and plants, increased water turbidity, and decreased dissolved oxygen concentrations or anoxia conditions (Zimmerman and Canuel 2002, Herrera-Silveira et al. 2004). Eutrophication will generate some problems such as increases in the frequency and spatial coverage of harmful algal blooms, degradation of water quality, and loss or degradation of submerged grasses. Consequently, eutrophication could cause death and decomposition of benthic organisms, and changes in the community structure of species, decreasing their diversity and increasing the dominance of resistant species (Cloern 2001, McGlathery 2001, Bricker et al. 2003, Herrera-Silveira et al. 2004, Karydis 2009, Kennish and Paerl 2010).

It has been demonstrated that once eutrophication occurs it is difficult to reverse, which in some cases may take several decades. This is why establishing management strategies for coastal lagoons based on data obtained by monitoring their environmental conditions, has become a necessity to prevent eutrophication (Anguiano-Cuevas et al. 2015, Cataudella et al. 2015, Le Fur et al. 2019). To assess the trophic status of marine environments, various models and indices have been developed.

One of these models is the trophic index of Karydis et al. (1983), which is specific for each nutrient. It was developed to evaluate the trophic state of marine environments taking into account the nutrient's loading of the area, specificity for each nutrient, and sensitivity to stressful concentration changes. Another one is the trophic index (TRIX) developed by Vollenweider et al. (1998), which includes the integration of physical, chemical, and biological variables (such as chlorophyll, oxygen saturation, mineral and total nitrogen and phosphorus) in its algorithm, and is applicable to inland and coastal marine waters. Moreover, referential values of the environmental conditions associated with the trophic conditions, such as those adopted by the Organization for Economic Co-operation and Development (OECD) are used (Vollenweider and Kerekes 1981). Considering 
the world experience in evaluating the trophic status of marine environments with these indices (despite they have not been validated with data from tropical systems), we propose to evaluate the trophic status of a tropical coastal lagoon called Punta de Piedras in Margarita Island, Venezuela, applying the above mentioned trophic indices for marine and coastal environments.

\section{MATERIALS AND METHODS}

\section{Study area}

Punta de Piedras Lagoon (Fig. 1) is a natural saline water body of $1300 \mathrm{~m}$ long and $900 \mathrm{~m}$ wide, surrounded by mangroves. It has a limited influence from the tidal cycle and communicates with the sea on its western side through a $200 \mathrm{~m}$ long channel. The lagoon has a maximum depth of $2.5 \mathrm{~m}$ and a maximum width of $25 \mathrm{~m}$ at the mouth (Cervigón and Gómez 1986, Llano 1987). This lagoon is a part of El Atolladar system and is located between a small village called Punta de Piedras and the Raya Lagoon, south of Margarita Island (Venezuela), between the parallels $10^{\circ} 54^{\prime} 19^{\prime \prime}-10^{\circ} 54^{\prime} 45^{\prime \prime} \mathrm{N}$ and $64^{\circ} 05^{\prime}$ 43"-64'06' 30" W (Voltolina and Voltolina 1978, Cervigón and Gómez 1986, Llano 1987).

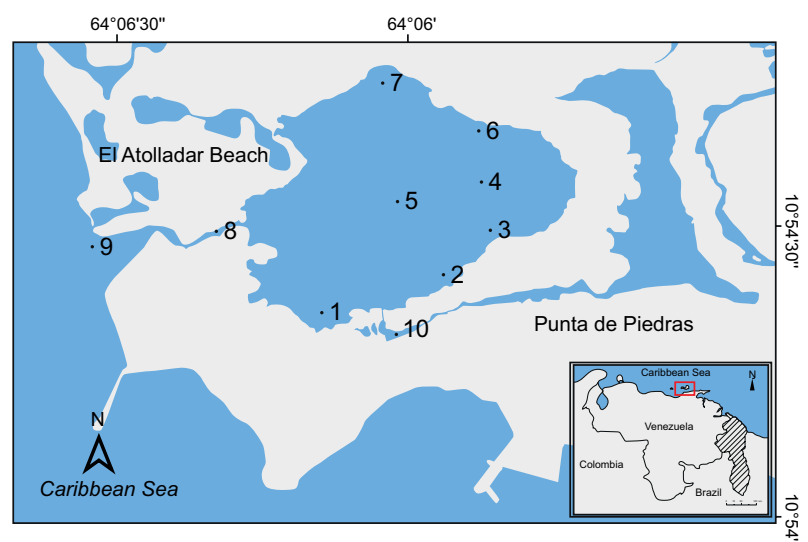

Fig. 1. Location of the sampling stations in Punta de Piedras Lagoon, Margarita island, Venezuela.

In addition to having ecological importance for the organisms that live there, this lagoon is used for shrimp farming and extraction of a great variety of fishes and mollusks of the Pinctada imbricata and Strombus pugilis species. Currently, there is a small industrial development in the vicinity of the lagoon with shrimp farms, fish processing plants, and fishing and port facilities, which together with the urban complex (more than 10000 inhabitants) are potential sources of contamination to the water body. In fact, some studies have confirmed that Punta de Piedras lagoon has undergone a considerable environmental degradation, especially in the water channel that borders the Paseo Esther Gil, located to the south of the lagoon (Lira 2001, Iriarte 2003).

\section{Sampling}

Ten sampling stations were selected: seven (stations 1-7) distributed in the interior of the lagoon (excluding the northeast extreme due to its shallow depth); one in the entrance channel (station 8), where the waters from shrimp farming are discharged; one in the marine and coastal environment (station 9) that communicates directly with the mouth of the lagoon, and one in the channel that borders the Paseo Esther Gil (station 10). In each sampling station, a sample without replicates was taken in the surface layer of the water during morning hours. This procedure was repeated monthly from February 2005 to January 2006. Temperature was measured using a mercury thermometer with $\mathrm{a} \pm 0.5^{\circ} \mathrm{C}$ precision; salinity (psu) with a digital induction salinometer (Strickland and Parsons 1972); dissolved oxygen (mg/L) by the Winkler's method modified by Aminot and Chaussepied (1983); chlorophyll- $a$ and pheopigments $(\mu \mathrm{g} / \mathrm{L})$ by the spectrophotometric method (Lorenzen 1967), and ammonium $(\mu \mathrm{g} / \mathrm{L})$, nitrites $(\mu \mathrm{g} / \mathrm{L})$, nitrates $(\mu \mathrm{g} / \mathrm{L})$, and orthophosphates $(\mu \mathrm{g} / \mathrm{L})$ by the methods outlined in Strickland and Parsons (1972) using a Milton-Roy Spectronic 501 spectrophotometer.

\section{Data analysis}

Data for chlorophyll- $a$, ammonium, nitrites, nitrates, and orthophosphates were included in the Karydis eutrophication index (Karydis et al. 1983).

$I=\frac{C}{C-\log _{10} x}+\log _{10} A$

where $\mathrm{I}$ is the eutrophication index, $C$ the logarithm of the total annual contributions of nutrients in the area, $x$ the total annual concentration of nutrients or chlorophyll- $a$ in one station, and $A$ the number of stations.

This index was calculated for each nutrient and for chlorophyll- $a$. A value greater than 5 is characteristic of eutrophic waters, while values between 3 and 5 correspond to mesotrophic waters and lower than 3 to oligotrophic waters (Karydis et al. 1983). Additionally, the TRIX trophic index was estimated 
according to the following equation (Vollenweider et al. 1998):

$$
T R I X=\frac{1}{1.2}\left[\log _{10}(C h l a \times D \% O \times N I D \times x P T)+1.5\right]
$$

where Chla is the chlorophyll- $a$ concentration $(\mu \mathrm{g} / \mathrm{l})$, $\mathrm{D} \% \mathrm{O}$ the 100-percentage of dissolved oxygen saturation, NID the concentration of dissolved inorganic nitrogen $(\mu \mathrm{g} / \mathrm{l})$, and $P T$ the total phosphorus concentration (phosphate concentration in $\mu \mathrm{g} / \mathrm{L}$ was used in this study). The values 1.2 and 1.5 are coefficients to set the lower limits of the index and the scale interval between 0 and 10 . The data obtained were compared with the classification scale indicated in Table $\mathbf{I}$. These indices were developed for marine and coastal waters in subtropical seas; however, they have been widely used in tropical environments around the world (Anguiano-Cuevas et al. 2015, López-Monroy and Troccoli-Ghinaglia 2018, Cutrim et al. 2019, Dewi et al. 2019).

Additionally, the data were compared with the limits established by the Organization for Economic Co-operation and Development (Table II, Vollenweider and Kerekes 1981). The data for each nutrient and chlorophyll- $a$ were graphed using the program Surfer 7.0.

\section{RESULTS}

\section{Environmental conditions}

The average temperature was $28.7 \pm 1.3{ }^{\circ} \mathrm{C}$ with the highest values in the central zone with an average of $29.5^{\circ} \mathrm{C}$ and the lowest in the southern zone with $27.5^{\circ} \mathrm{C}$. Temporarily, two maximum temperatures were detected, the first in June and the second between October and November with an average temperature of $30.4^{\circ} \mathrm{C}$, while the lowest temperatures were registered between January and February at $26^{\circ} \mathrm{C}$. Salinity showed an average of $38.31 \pm 1.72 \mathrm{~g} / \mathrm{kg}$ without important differences among stations. The highest monthly values were measured in February and August with an average of $39.27 \mathrm{~g} / \mathrm{kg}$ and the lowest in September and December with 35.33 and $36.1 \mathrm{~g} / \mathrm{kg}$, respectively. The mean dissolved oxygen concentration was $5.65 \pm 1.71 \mathrm{mg} / \mathrm{L}$, having the lowest values in the station near Paseo Esther Gil (E10) with an average of $3.80 \mathrm{mg} / \mathrm{L}$ and the highest in the stations closest to the mouth $(1,8$, and 9) with an average of $6.73 \mathrm{mg} / \mathrm{L}$. Temporarily, the lowest values were determined in August and September with $3.97 \mathrm{mg} / \mathrm{L}$ and the highest in June with $8.44 \mathrm{mg} / \mathrm{L}$. The rest of the months form a homogeneous group with an average of $5.57 \mathrm{mg} / \mathrm{L}$ (Pereira et al. 2019, Table III).

TABLE I. CLASSIFICATION OF THE TROPHIC STATE OF ESTUARINE WATERS ACCORDING TO THE TROPHIC INDEX TRIX.

\begin{tabular}{|c|c|c|c|}
\hline TRIX & Condition & Water quality & Trophic state \\
\hline$<2$ & Very unproductive water and very low trophic status & Excellent & Ultra-oligotrophic \\
\hline $2-4$ & Unproductive water and low trophic status & High & Oligotrophic \\
\hline $4-5$ & Moderately productive water and medium trophic status & Good & Mesotrophic \\
\hline $5-6$ & Moderate to very productive water and high trophic status & Moderate & Mesotrophic to eutrophic \\
\hline $6-8$ & Very productive water and high trophic status & Poor & Eutrophic \\
\hline$>8$ & Highly productive water and the highest trophic status & Very poor & Hyper-eutrophic \\
\hline
\end{tabular}

Source: Cutrim et al. (2019)

TABLE II. CLASSIFICATION OF THE TROPHIC STATE ESTABLISHED BY THE OECD BASED ON THE CONCENTRATIONS OF PHOSPHORUS, CHLOROPHYLL- $A$, AND SECCHI DEPTH.

\begin{tabular}{lcccc}
\hline Trophic state & $\begin{array}{c}\text { Total mean } \\
\text { phosphorus }(\mu \mathrm{g} / \mathrm{L})\end{array}$ & $\begin{array}{c}\text { Total mean } \\
\text { chlorophyll- } a(\mu \mathrm{g} / \mathrm{L})\end{array}$ & $\begin{array}{c}\text { Chlorophyll- } a \\
\text { maximum }(\mu \mathrm{g} / \mathrm{L})\end{array}$ & $\begin{array}{c}\text { Mean Secchi } \\
\text { depth }(\mathrm{m})\end{array}$ \\
\hline Ultra-oligotrophic & $<4$ & $<1$ & $<2.5$ & $>12$ \\
Oligotrophic & $4-10$ & $1-2.5$ & $2.5-8$ & $6-12$ \\
Mesotrophic & $10-35$ & $2.5-8$ & $8-25$ & $6-3$ \\
Eutrophic & $35-100$ & $8-25$ & $25-75$ & $3-1.5$ \\
Hyper-eutrophic & $>100$ & $>25$ & $>75$ & $<1.5$ \\
\hline
\end{tabular}

Source: Toner et al. (2005). 


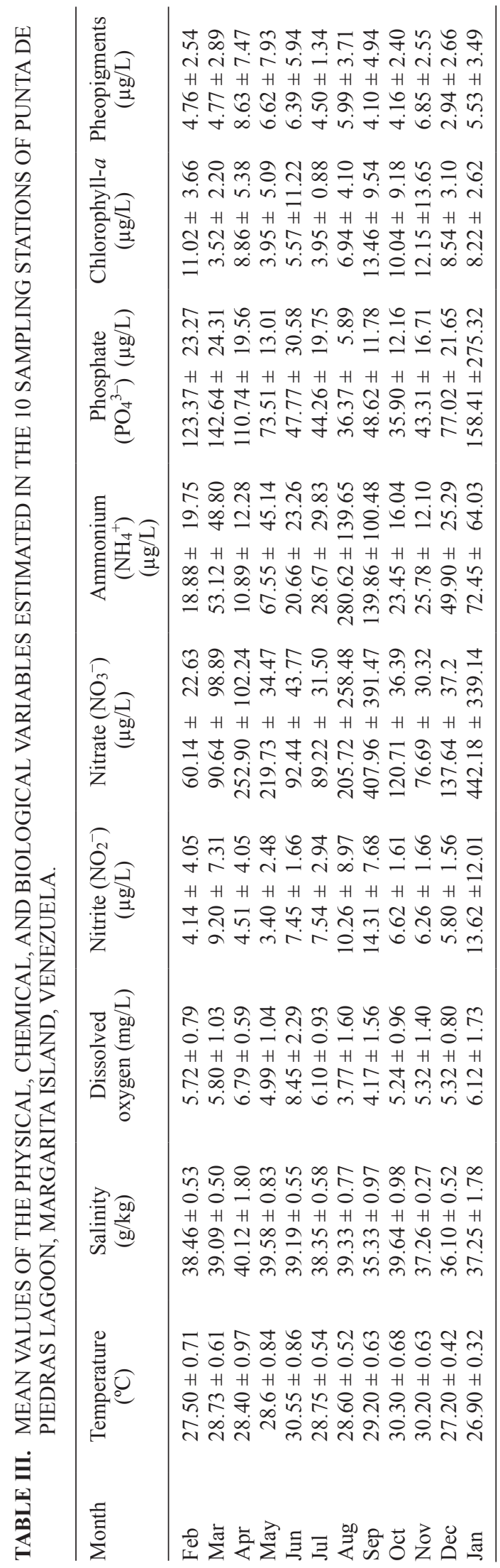

Regarding pigments, the average chlorophyll- $a$ concentration was $9.5 \pm 7.43 \mu \mathrm{g} / \mathrm{L}$. Spatially, E3 and E10 differed from the rest of the stations, presenting averages of 5.64 and $16.18 \mu \mathrm{g} / \mathrm{L}$, respectively. The lowest values were estimated in March, May, and July, with averages of $3.42,6.19$, and $4.38 \mu \mathrm{g} / \mathrm{L}$, respectively, while highest were measured in September and November with 17.2 and $18.48 \mu \mathrm{g} / \mathrm{L}$, respectively. The mean concentration of pheopigments was $5.43 \pm 4.51 \mu \mathrm{g} / \mathrm{L}$ with the highest values in the southern and central stations of the lagoon and the lowest in the mouth and northern stations. Temporarily, there were changes during all year reaching the highest value in April and November with averages of $8.63 \mu \mathrm{g} / \mathrm{L}$ and $6.85 \mu \mathrm{g} / \mathrm{L}$, respectively (Pereira et al. 2019, Table III).

Regarding nutrients, an average ammonium concentration of $66.06 \pm 67.34 \mu \mathrm{g} / \mathrm{L}$ was estimated, having the highest values in the station close to Paseo Esther Gil (E10) with an average of $81.54 \mu \mathrm{g} / \mathrm{L}$, as a result of the contributions of wastewater that drains in this sector of the lagoon. The lowest values were estimated at station 4 with an average of $34.02 \mu \mathrm{g} / \mathrm{L}$. Temporarily, ammonium varied continuously during the year, obtaining two maxima in August and September with averages of 280.62 and $139.86 \mu \mathrm{g} / \mathrm{L}$, respectively. The nitrites mean was $7.50 \pm 6.31 \mu \mathrm{g} / \mathrm{L}$, having higher values in stations 7 and 10 with 10.58 and $11.50 \mu \mathrm{g} / \mathrm{L}$, respectively, and the lowest averages in the central stations of the lagoon (E4 and E5) with $5.06 \mu \mathrm{g} / \mathrm{L}$. Temporarily, three maxima were observed: one in March with an average of $9.20 \mu \mathrm{g} / \mathrm{L}$, the highest one in September with $14.31 \mu \mathrm{g} / \mathrm{L}$, and the last one in January with $13.62 \mu \mathrm{g} / \mathrm{L}$. The lowest values were found in May with $3.40 \mu \mathrm{g} / \mathrm{L}$. The average concentration of nitrates was $282.90 \pm 204.99 \mu \mathrm{g} / \mathrm{L}$, having a pattern similar to that of nitrites: a maximum in April with an average of $252.90 \mu \mathrm{g} / \mathrm{L}$, another in September with $407.96 \mu \mathrm{g} / \mathrm{L}$, and the last and highest in January with $442.18 \mu \mathrm{g} / \mathrm{L}$. The lowest values were found in February with $60.14 \mu \mathrm{g} / \mathrm{L}$. Finally, the average concentration of phosphates was $78.49 \pm 88.56 \mu \mathrm{g} / \mathrm{L}$ with a different pattern for nitrogen, in which two welldifferentiated seasons were evident: one from June to November with an average of $42.74 \mu \mathrm{g} / \mathrm{L}$ and the rest of the months with higher values with an average of $113.97 \mu \mathrm{g} / \mathrm{L}$ (Pereira et al. 2019, Table III).

\section{Thophic indices}

In most of the stations, the Karydis eutrophication index calculated for ammonium was higher than 3, corresponding to mesotrophic waters (Fig. 2). Only 

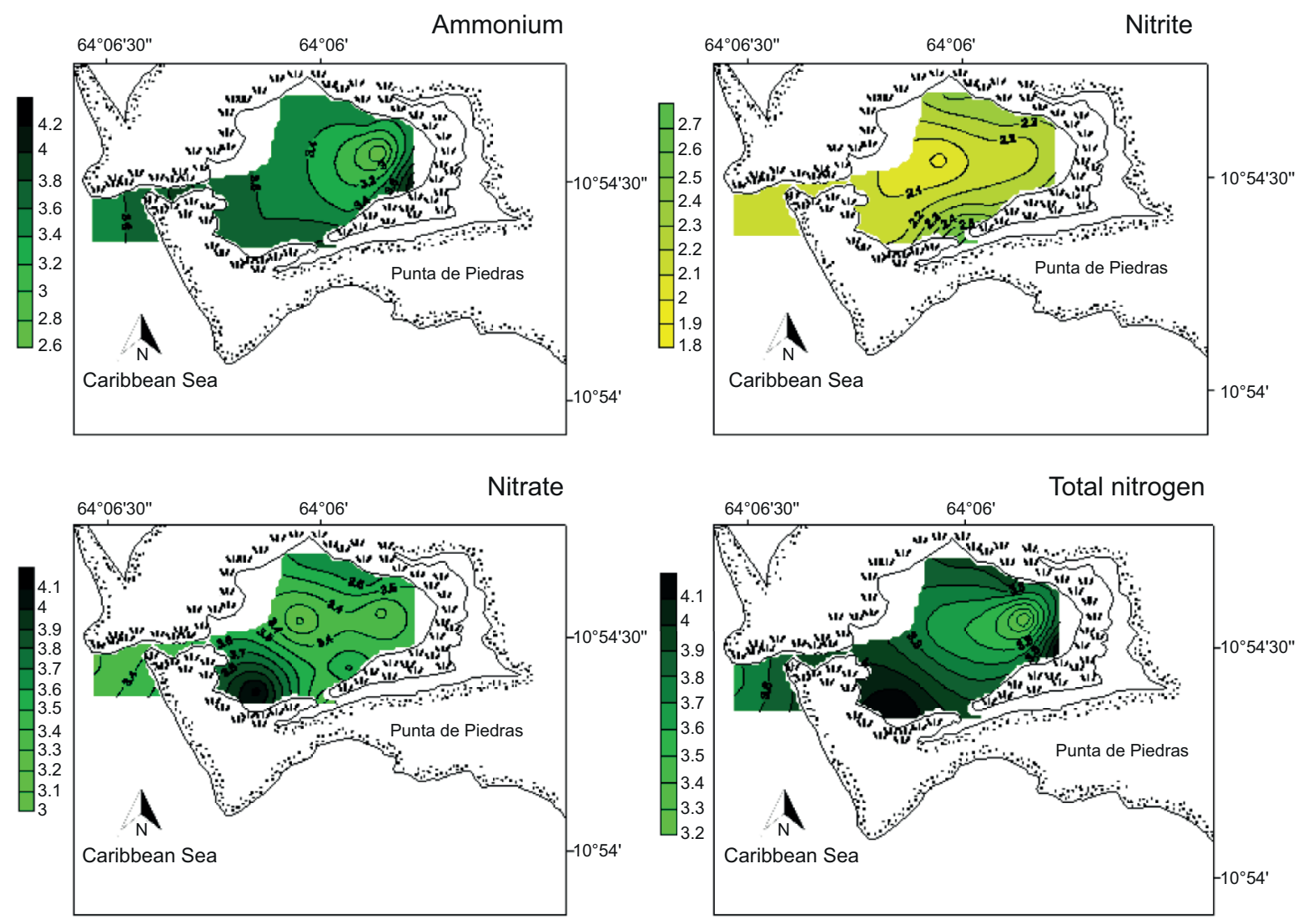

Fig. 2. Karydis eutrophication index for the concentrations of nitrogenated nutrients by stations in surface waters of Punta de Piedras Lagoon, Venezuela.

in station 4, the index was lower than 3 , indicating the presence of oligotrophic waters. The Karydis index determined for nitrite concentrations varied from 2 to 2.8 , which corresponds to the category of oligotrophic waters, while for nitrates the index fluctuated between 3.2 and 4.1, corresponding to mesotrophic waters (Fig. 2). This index applied for the sum of inorganic nitrogenous nutrients as a single factor and chlorophyll- $a$ concentration, varied between 3.7 and 4.3, corresponding to mesotrophic waters (Fig. 3). It is important to note that values of 5 were estimated in the case of chlorophyll- $a$ for the station closest
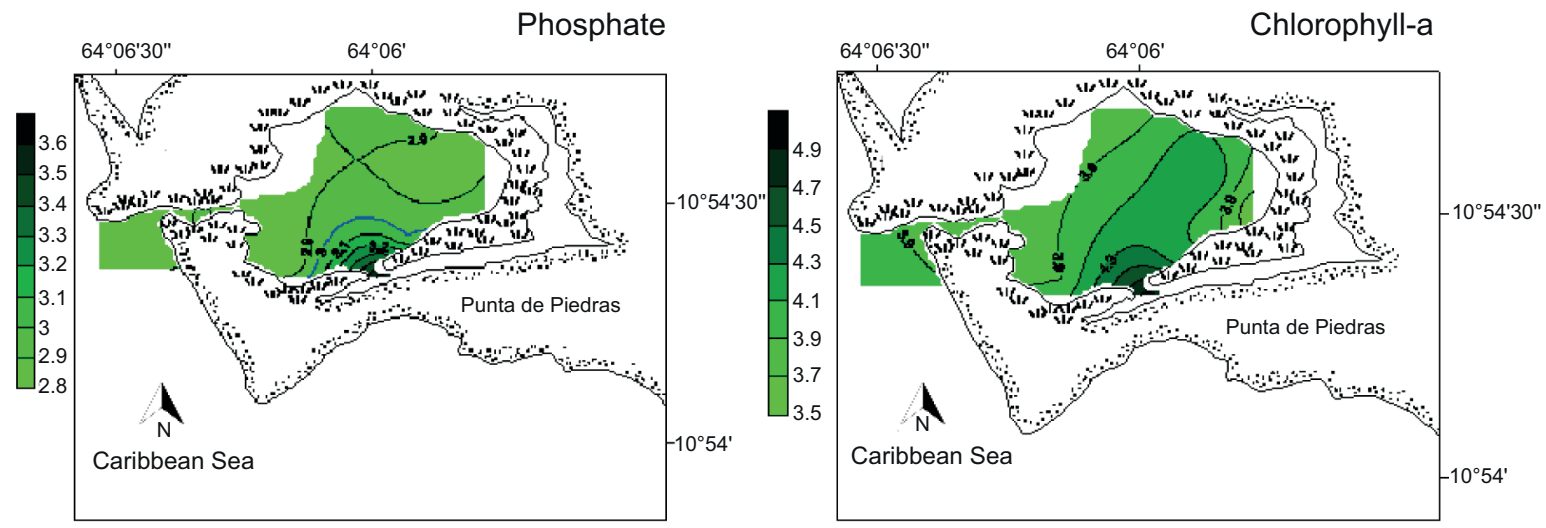

Fig. 3. Karydis eutrophication index for the concentrations of phosphate and chlorophyll- $a$ by stations in surface waters of Punta de Piedras Lagoon, Venezuela. 
to Paseo Esther Gil (E10), corresponding to waters on the border between mesotrophic and eutrophic conditions. Relating to phosphate concentrations, estimated values indicated oligotrophic conditions, except for stations 2,3 , and 10 , corresponding to the southern area of the lagoon and which also have a greater influence on the part of the adjacent urban development (Fig. 3).

Concerning the TRIX trophic index, an average value of 3.3 was estimated with an interval between 2.72 and 3.94, demonstrating oligotrophy for entire lagoon (Fig. 4) throughout the study time (Fig. 5). However, when comparing the average values of phosphates with the limits established by the OECD, eutrophic conditions were obtained for most of the months except for the first four months of the year, which presented hypertrophic conditions having phosphorus concentrations higher than $100 \mu \mathrm{g} / \mathrm{L}$. Chlorophyll- $a$ concentrations indicated mesotrophic

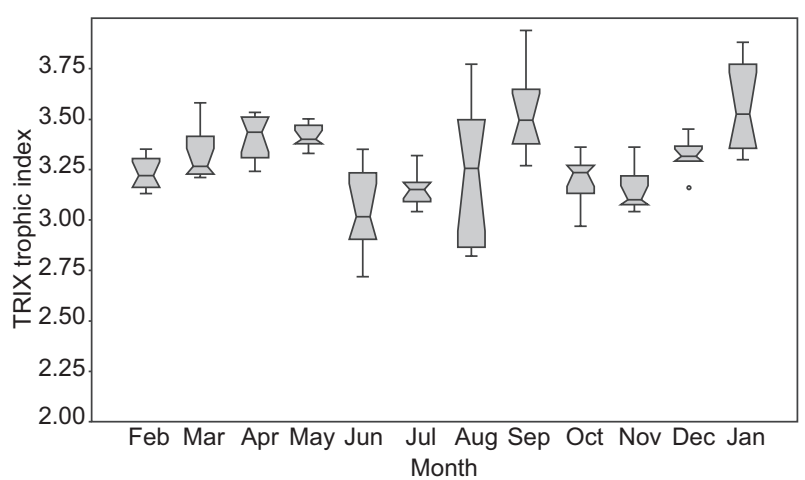

Fig. 4. Spatial variation of the TRIX trophic index in Punta de Piedras Lagoon, Venezuela.

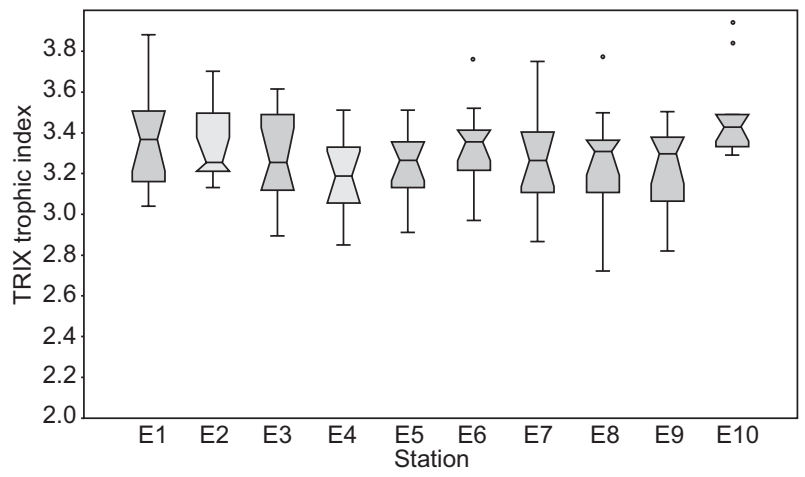

Fig. 5. Temporary variation of the TRIX trophic index in Punta de Piedras Lagoon, Venezuela. and eutrophic conditions with spatial and temporal variations. Temporarily, March and from May to $\mathrm{Au}-$ gust were included in the mesotrophic category while the rest of the months in the eutrophic one. Spatially, only the internal stations of the southern zone (E1, $\mathrm{E} 2$, and E10) and the central zone (E5) were in the eutrophic category for this variable, while the rest of the lagoon was considered mesotrophic.

\section{DISCUSSION}

The results obtained in this research indicate different trophic conditions depending on the indices applied. For example, the Karidys index showed mesotrophic conditions for nitrates, ammonium, and chlorophyll- $a$, while oligotrophic conditions were estimated for nitrites and phosphates. TRIX indicated oligotrophic conditions for the whole body of the lagoon during the study period. These differences were further accentuated when comparing the concentrations of phosphorus and chlorophyll- $a$ with the reference values established by the OECD for the classification of coastal systems according to their status. Using those reference values, Punta de Piedras lagoon could be classified as eutrophic to hypertrophic.

Karydis (2009) defined mesotrophy as an intermediate condition between low production systems with low concentrations of nutrients and nutrient-rich systems with high algal biomass. A mesotrophic water body presents moderate productivity and concentrations of nutrients that allow the development of primary producers without negatively affecting the rest of the representatives of the trophic web (Istvánovics 2009, Primpas and Karydis 2011, Ganguly et al. 2015, Cutrim et al. 2019). Furthermore, the average concentrations of phosphate and chlorophyll does not exceed $35 \mu \mathrm{g} / \mathrm{L}$ and $8 \mu \mathrm{g} / \mathrm{L}$, respectively (Vollenweider and Kerekes 1981). In fact, chlorophyll- $a$ usually increases only when temperature increases and there is a recharge of nutrients in the system, for example in spring in the case of water bodies in high latitudes (Istvánovics 2009). Additionally, under mesotrophic conditions, periodic ephemeral macroalgae blooms often occur (Kennish and Paerl 2010).

Although Punta de Piedras lagoon showed high nutrient concentrations, there was no evidence of the occurrence of eutrophication. This same phenomenon was found in some coastal zones of the Yucatan Peninsula, Mexico (Herrera-Silveira et al. 2004), in Las Marites lagoon, another coastal lagoon on Margarita Island (López-Monroy and TroccoliGhinaglia 2018), and in a subtropical lagoon in Brazil 
(Hennemann and Petrucio 2011). In both cases, TRIX indicated no eutrophication despite the presence of high concentrations of nutrients and organic matter. Eutrophication is a complex phenomenon involving harmful algal blooms and the mortality of fish and benthic organisms. It also entails the depletion of oxygen concentrations, overgrowth of both microscopic and macroscopic primary producers, and other consequences that affect the scenic value and health of the water body (Cloern 2001, McGlathery 2001, Karydis 2009, Kennish and Paerl 2010). Otherwise, different trophic indices were applied with similar results in a study carried out in the Iranian coasts of the Caspian Sea, concluding that any of them could be used (Nasrollahzadeh et al. 2019).

One of the aspects to consider in the use of these indices is that they were developed with data from coastal lagoons in the Mediterranean Sea (Vollenweider and Kerekes 1981). Thus, adaptations should be made for their implementation based on historical data on the environmental conditions of tropical lagoons. In fact, Primpas and Karydis (2010) proposed an adaptation on the TRIX scale because the design of this index only considered environments with high concentrations of nutrients and phytoplanktonic biomass, excluding oligotrophic systems. If this scale had been used, a mesotrophic condition in Punta de Piedras lagoon would be obtained, as it was estimated when using the Karydis trophic index. Additionally, the efficiency of this model in coastal lagoons has been disputed (Salas et al. 2008).

The design of these indices has particular considerations. In the case of the Karydis index, data of a single variable are used for its estimation, while TRIX is based on a linear combination of algorithms for four environmental variables related to the cause, state, and impact of the process of eutrophication. Although all of these are widely used for their ease of application, each of them has its limitations. In fact, it has been considered in different studies that these indices do not cover a wide range of trophic conditions because they do not consider all the important variables (Pérez-Ruzafa et al. 2007, Karydis 2009, Brito et al. 2012, Béjaoui et al. 2018). Indeed, Karydis (2009) discussed some difficulties related to the determination of the trophic state of a water bodies, which include discrimination between natural and anthropogenic sources of nutrients, the redundancy that could be generated when considering several interrelated variables, the deviation of the normality in the distribution of the variables, and the applicability of the algorithms in all aquatic systems, among others.
For eutrophication to occur in a water body, additional conditions to the continuous contribution of nutrients to the system are necessary, being one of the most important a restricted circulation of water (Kennish and Paerl 2010), which could explain why the eutrophication phenomenon does not occur in Punta de Piedras lagoon. This water body has a simple configuration with few mangrove channels that facilitate the circulation of water (Pereira et al. 2019). In fact, water in the lagoon is removed about 75 times a year, at a rate of 4.85 days for each renovation, having a volume of $1643 \mathrm{~m}^{3} / \mathrm{s}$ entering the lagoon through its main channel and an outgoing volume of $1570 \mathrm{~m}^{3} / \mathrm{s}$ (Zamakona 1986).

The residence time of water, in which this element remains in the environment with all its components strongly affects the level of primary production and therefore the trophic level of the water body (Boynton et al. 1996). The permanence of a water mass inside a lagoon is affected by its hydrographic conditions, which may also considerably affect the chemical form of the nutrients and water transparency, a factor that influences the light penetration for photosynthesis (Bystrom et al. 2000). Factors such as exchange of tides, flow of freshwater, and circulation of water masses vary the susceptibility to the discharge of nutrients from one water body to another, manifesting in the trophic state (Cloern 1999, Boesch 2002). In many estuaries, high concentrations of nutrients have apparently caused small effects, but in others where the entry of nutrients into the body of water is low, eutrophic conditions have been observed, which indicates that many factors and complex interactions with the ecosystem as a whole are decisive for this phenomenon to occur (Cotovicz et al. 2013, LópezMonroy and Troccoli-Ghinaglia 2018).

Despite showing mesotrophic conditions, it is important to highlight a special characteristic of the pollution observed in the channel adjacent to Paseo Esther Gil, in the southern area of the lagoon. This area receives considerable contributions of nutrients that, together with its scarce circulation of water, generate an hypoxic state and an increase in phytoplankton biomass, which are symptoms of eutrophication (Zimmerman and Canuel 2002, Herrera-Silveira et al. 2004). This phenomenon was observed especially during the months with maximum rainfall and the greatest effect of trade winds (Pereira et al. 2019). According to AnguianoCuevas et al. (2015), this condition of pollution occurs due to oxygen consumption of microorganisms to degrade organic matter and other nutritional elements. This phenomenon has been reported by 
Romero et al. (2004) in a lagoon system adjacent to an agricultural area in southeastern Mexico, explaining the effect of the resuspension of organic matter by the wind and the subsequent increase in the demand for dissolved oxygen in areas with poor water circulation.

An important element for discussing the condition presented in this locality is phosphate concentration, which was 2.5 times higher compared to the rest of the water body. This is due to the contributions of sewage from the adjacent community (Lira 2001). In fact, the Karydis trophic index for phosphate was low in all the lagoon except in station 10, where it was clearly mesotrophic, which could indicate that phosphate is a limiting nutrient for the growth of the phytoplankton community (Falcão and Vale 2003). In addition, a negative correlation was observed between the concentration of chlorophyll- $a$ with dissolved oxygen and pheopigments, these last being found in low concentrations.

Another factor that could favor the absence of eutrophication in Punta de Piedras lagoon is the intensity of winds, since according to data provided by Punta de Piedras meteorological station this zone presented an average speed of $15.9 \mathrm{~km} / \mathrm{h}$ during the study. This variable facilitates mixing processes in the water column and keeps it oxygenated. This same effect was observed by López-Monroy and TroccoliGhinaglia (2018) in Marites lagoon, also located in the southern area of Margarita Island.

In order to complement the studies related to the trophic state it is recommended to consider another important variable, the Secchi depth, which is a measure of water transparency (Istvánovics 2009). However, Punta de Piedras lagoon is a shallow water body that did not exceed $2 \mathrm{~m}$ in depth in the established sampling stations, and the Secchi disk was visualized in the seabed for most of the study period, so the penetration of light in the water column is not considered a limiting factor for the occurrence of photosynthesis. In spite of the differences obtained between the different indices used, a mesotrophic condition was measured at Punta de Piedras lagoon, which has high concentrations of nutrients that do not affect its trophic status as a result of its hydrographic conditions. Nevertheless, due to the signs of environmental deterioration observed in the southern area of the lagoon and the importance of this water body for the inhabitants of the area, it is advisable to keep track of its environmental conditions and the continuous flow of water at the mouth of the lagoon.

Likewise, it is necessary to prevent wastewater from reaching the lagoon and adequately manage the waste generated during fishing and shellfish processing activities that take place in the lagoon to avoid overloading of nutrients to the system. Although eutrophication has been successfully reversed in various water bodies by managing the release of nutrients by human activities (Istvánovics 2009), it must be considered that prevention generates fewer economical costs than an ecological restoration process. Oligotrophization, which is the reverse phenomenon of eutrophication, is not always a simple process and it can take decades for a water body to return to conditions similar to the initial ones (Livingston 2000, McCrackin et al. 2017, Le Fur et al. 2019). Evaluating the results obtained in this study, the Karidys index seems to be a more adjusted model to explain the trophic conditions of Punta de Piedras lagoon because it has high concentration of some nutrients and chlorophyll $a$ without the symptoms described for eutrophic systems. However, studies to validate specific models for tropical marine and coastal systems are required.

\section{ACKNOWLEDGMENTS}

This study was funded by the Research Council of the Universidad de Oriente, Núcleo Nueva Esparta, and is part of the project CI-6-030602-1214/05 "Physical-chemical characterization of the Punta de Piedras Lagoon".

\section{REFERENCES}

Aminot A. and Chaussepied M. (1983). Manuel des analyses chimiques en Milieu Marin. Centre National pour L'Exploitation des Océans, Paris, France, 395 pp. Anguiano-Cuevas J., Olivos-Ortiz A., Cervantes O., AzuzAdeath I., Ramírez-Álvarez N. and Rivera-Rodríguez M. (2015). Evaluation of trophic state in the Palo Verde estuary (Colima, México), action to regulating agricultural activities. J. Integr. Coast. Zone Manag. 15(4), 507-522. https://doi.org/10.5894/rgci582

Béjaoui B., Ottaviani E., Barelli E., Ziadi B., Dhib A., Lavoie M., Gianluca C., Turki S., Solidoro C. and Aleya L. (2018). Machine learning predictions of trophic status indicators and plankton dynamic in coastal lagoons. Ecol. Indic. 95, 765-774. https://doi. org/10.1016/j.ecolind.2018.08.041

Boesch D. (2002). Challenges and opportunities for science in reducing nutrient over-enrichment of coastal ecosystems. Estuaries 25, 744-758. https://doi. org/10.1007/BF02804914 
Boynton W., Murray L., Hagy J., Stokes C. and Kemp W. (1996). A comparative analysis of eutrophication patterns in a temperate coastal lagoon. Estuaries 19(2B), 408-421. https://doi.org/10.2307/1352459

Bricker S., Ferreira J. and Simas T. (2003). An integrated methodology for assessment of estuarine trophic status. Ecol. Model. 169, 39-60. https://doi.org/10.1016/ S0304-3800(03)00199-6

Brito A., Quental T., Coutinho T., Branco A., Falcão M., Newton A., Icely J. and Moita T. (2012). Phytoplankton dynamics in southern Portuguese coastal lagoons during a discontinuous period of 40 years: an overview. Estuar. Coast. Shelf Sci. 110, 147-156. https://doi. org/10.1016/j.ecss.2012.04.014

Bystrom O., Andersson H. and Gren I. (2000). Economic criteria for using wetlands as nitrogen sinks under uncertainty. Ecol. Econ. 35, 35-45. https://doi. org/10.1016/S0921-8009(00)00166-X

Cataudella S., Crosetti D. and Massa F. (2015). Mediterranean coastal lagoons: sustainable management and interactions among aquaculture, capture fisheries and the environment. Food and Agriculture Organization of the United Nations, Rome, Italy, $278 \mathrm{pp}$.

Cervigón F. and Gómez A. (1986). Las lagunas litorales de la Isla de Margarita. Centro de Investigaciones de la Universidad de Oriente-Editorial Arte, Caracas, Venezuela, $88 \mathrm{pp}$.

Cloern J. (1999). The relative importance of light and nutrient limitation of phytoplankton growth: a simple index of coastal ecosystem sensitivity to nutrient enrichment. Aquatic Ecol. 33, 3-16. https://doi. org/10.1023/A:1009952125558

Cloern J. (2001). Our evolving conceptual model of the coastal eutrophication problem. Mar. Ecol. Prog. Ser. 210, 223-253. https://doi.org/10.3354/meps 210223

Contreras F., Castañeda O., García A. and Gutiérrez F. (1995). Nutrientes en 39 lagunas costeras mexicanas, Informe Técnico. . Departamento de Hidrobiología, Universidad Autónoma Metropolitana-Iztapalapa, Mexico, 76 pp.

Cotovicz L., Brandini N., Knoppers B., Mizerkowski B., Sterza J., Coelho A. and Petter P. (2013). Assessment of the trophic status of four coastal lagoons and one estuarine delta, eastern Brazil. Environ. Monit. Assess. 185, 3297-3311. https://doi.org/10.1007/s10661-012-2791-x

Cutrim M., Santos F., Duarte A., Furtado L., de Oliveira B., Gomes A. Adorno J. and Lima A. (2019). Trophic state of an urban coastal lagoon (northern Brazil), seasonal variation of the phytoplankton community and environmental variables. Estuar. Coast. Shelf Sci. 216, 98-109. https://doi.org/10.1016/j.ecss.2018.08.013

Dewi R., Zainuri M., Anggoro S., Winanto T., Endrawati H., Hadisusanto S., Sabdono A., Haeruddin C., Mus- kananfola M. and Nugroho D. (2019). Tropic status assessment in Segara Anakan Lagoon, Indonesia: experience in applying the trophic index TRIX. IOP Conf. Series: Earth Environ. Sci. 255, 012032. https:// doi.org/10.1088/1755-1315/255/1/012032.

Falcão M. and Vale C. (2003). Nutrient dynamics in a coastal lagoon (Ria Formosa, Portugal): The importance of lagoon-sea water exchanges on the biological productivity. Cienc. Mar. 29(3), 425-433. https://doi. org $/ 10.7773 / \mathrm{cm} . v 29 \mathrm{i} 4.173$

Fisher T., Jordan T., Staver K., Gustafson A., Koskelo A., Fox R., Sutton A., Kana T., Beckert K., Stone J., McCarty G. and Lang M. (2010). The Choptank Basin in transition: intensifying agriculture, slow urbanization, and estuarine eutrophication. In: Coastal lagoon: critical habitats of environmental change (Kennish M. and Paerl H., Eds.). CRC Press, Taylor \& Francis Group, USA, $539 \mathrm{pp}$.

Ganguly D., Patra S., Muduli P., Vardhan K., Abhilash K., Robin R. and Subramanian B. (2015). Influence of nutrient input on the trophic state of a tropical brackish water lagoon. J. Earth Syst. Sci. 124(5), 1005-1017. https://doi.org/10.1007/s12040-015-0582-9

Hennemann M. and Petrucio M. (2011). Spatial and temporal dynamic of trophic relevant parameters in a subtropical coastal lagoon in Brazil. Environ. Monit. Assess. 181, 347-361. https://doi.org/10.1007/s10661010-1833-5

Herrera-Silveira J., Troccoli L., Comin F. and Madden C. (2004). Eutrofización costera en la Península de Yucatán. Diagnóstico ambiental del Golfo de México (Vol. 2). Informe técnico. Instituto Nacional de Ecología, Yucatán, $823 \mathrm{pp}$.

Iriarte R. (2003). Contaminación cloacal en la Laguna de Punta de Piedras, Municipio Tubores, Isla de Margarita, Venezuela. Informe Técnico. Estación de Investigaciones Marinas, Fundación La Salle de Ciencias Naturales, Punta de Piedras, Venezuela, 49 pp.

Istvánovics V. (2009). Eutrophication of lakes and reservoirs. In: Encyclopedia of inland waters (Likens G., Ed.). Academic Press, Elsevier, Oxford, UK, 157-165. https://doi.org/10.1016/B978-012370626-3.00141-1

Karydis M., Ignatiades L. and Moschopoulou N. (1983). An index associated with nutrient eutrophication in the marine environment. Estuar. Coast. Shelf Sci. 16, 339344. https://doi.org/10.1016/0272-7714(83)90151-8

Karydis M. (2009). Eutrophication assessment of coastal waters based on indicators: a literature review. Global NEST J. 11(4), 373-390. https://doi.org/10.30955/ gnj.000626

Kennish M. and Paerl H., Eds. (2010). Coastal lagoon: critical habitats of environmental change. CRC Press, Taylor \& Francis Group, USA, 539 pp. https://doi. 
org/10.1201/EBK1420088304

Le Fur I., De Wit R., Plus M., Oheix J., Derolez V., Simier M., Malet N. and Ouisse V. (2019). Re-oligotrophication trajectories of macrophyte assemblages in Mediterranean coastal lagoons based on 17-year time-series. Mar. Ecol. Prog. Ser. 608, 13-32. https:// doi.org/10.3354/meps 12814

Lee J. and Arega F. (1999). Eutrophication dynamics of Tolo Harbour, Hong Kong. Mar. Poll. Bul. 39(1-2), 187-192. https://doi.org/10.1016/S0025-326X(99)00007-7

Lira C. (2001). Saneamiento y recuperación integral de la Laguna de Punta de Piedras, Municipio José Celedonio Tubores, Edo. Nueva Esparta. Informe técnico. Alcaldía de Tubores, Isla de Margarita, Venezuela, 65 pp.

Livingston R.J. (2000). Eutrophication processes in coastal systems - origin and succession of plankton blooms and effects on secondary production in gulf coast estuaries. CRC Press, Boca Raton, Florida, 352 pp.

Llano M. (1987). Dinámica sedimentaria de la Laguna de Punta de Piedras. Épocas de mareas mínimas. Mem. Soc. Cienc. Nat. La Salle 47(127-128), 37-75.

López-Monroy F. and Troccoli-Ghinaglia L. (2018). Aplicación de índices de estado trófico en la laguna costera tropical Las Marites (isla de Margarita, Venezuela). Saber, Univ. Oriente, Venez. 30, 151-159.

Lorenzen C. (1967). Determination of chlorophyll and pheopigments: spectrophotometric equations. Limnol. Oceanogr. 12(2), 343-346. https://doi.org/10.4319/ lo.1967.12.2.0343

McCrackin M., Jones H., Jones P. and Moreno-Mateos D. (2017) Recovery of lakes and coastal marine ecosystems from eutrophication: a global meta-analysis. Limnol. Oceanogr. 62, 507-518. https://doi.org/10.1002/ LNO.10441

McGlathery K. (2001). Macroalgal blooms contribute to the decline of seagrass in nutrient-enriched coastal waters. J. Phycol. 37(4), 453-456. https://doi. org/10.1046/j.1529-8817.2001.037004453.x

Nasrollahzadeh Saravi H., Pourang N., Foong S. and Makhlough A. (2019). Eutrophication and trophic status using different indices: A study in the Iranian coastal waters of the Caspian Sea. Iran. J. Fish. Sci. 18(3), 531-546. https://doi.org/10.22092/ijfs.2018.117717

Nixon S. (1995). Coastal marine eutrophication: a definition, social causes, and future concerns. Ophelia 41, 199-219. https://doi.org/10.1080/00785236.1995.10 422044

Pereira C., López-Monroy F., Salazar K. and Colmenárez I. (2019). Condiciones hidrográficas de la laguna de Punta de Piedras, Isla de Margarita, Venezuela. Bol. Inst. Oceanogr. Venez. 57(2), 1-11.

Pérez-Ruzafa A., Mompeán M. and Marcos C. (2007). Hydrographic, geomorphologic and fish assemblage relationships in coastal lagoons. Hydrobiol. 577, 107125. https://doi.org/10.1007/s10750-006-0421-8

Pérez-Ruzafa A., Marcos C. and Pérez-Ruzafa I. (2011). Recent advances in coastal lagoons ecology: evolving old ideas and assumptions. Transit. Waters Bull. 5(1), 50-74. https://doi.org/10.1285/i1825229Xv5n1p50

Pérez-Ruzafa A., Morkune R., Marcos C., Pérez-Ruzafa I. M. and Razinkovas-Baziukas A. (2020). Can an oligotrophic coastal lagoon support high biological productivity? Sources and pathways of primary production. Mar. Environ. Res. 153, 104824. https://doi. org/10.1016/j.marenvres.2019.104824

Potts T., Burdon D., Jachson E., Atkins J., Saunders J., Hastings E. and Langmead O. (2014). Do marine protected areas deliver flows of ecosystems services to support human welfare? Mar. Policy 44, 139-148. https://doi.org/10.1016/j.marpol.2013.08.011

Primpas I. and Karydis M. (2011). Scaling the trophic index (TRIX) in oligotrophic marine environments. Environ. Monit. Assess. 178, 257-269. https://doi. org/10.1007/s10661-010-1687-x

Romero A., Hernández C., Malo E. and Mendoza R. (2004). Water quality and presence of pesticides in a tropical coastal wetland in southern Mexico. Mar. Pollut. Bull. 48(11-12), 1130-1141. https://doi. org/10.1016/j.marpolbul.2004.01.003

Salas F., Teixeira H., Marcos C., Marques J. and Pérez-Ruzafa A. (2008). Applicability of the trophic index TRIX in two transitional ecosystems: the Mar Menor lagoon (Spain) and the Mondego estuary (Portugal). ICES J. Mar. Sci. 65, 1442-1448. https://doi.org/10.1093/icesjms/fsn123

Strickland J. and Parsons T. (1972). A practical handbook of seawater analysis. J. Fish. Res. Board Can. 167, 1-310. https://doi.org/10.1002/iroh.19700550118

Toner P., Bowman J., Clabby K., Lucey J., McGarrigle M., Concannon C., Clenaghan C., Cunningham P., Delaney J., O’Boyle S., MacCárthaigh M., Craig M. and Quinn R. (2005). Water quality in Ireland 2001-2003. Environmental Protection Agency, Ireland, 164 pp.

Vollenweider R. and Kerekes J. (1981). Background and summary results of the OECD cooperative programme on eutrophication. In: The OECD cooperative program on eutrophication (and L. Janus and Vollenweider R., Eds.). Scientific Series No. 131-S, Ontario, Canada.

Vollenweider R., Giovanardi F., Montanari G. and Rinaldi A. (1998). Characterization of the trophic conditions of marine coastal waters with special reference to the NW Adriatic Sea: proposal for a trophic scale, turbidity and generalized water quality index. Environmetrics 9, 329-357. https://doi.org/10.1002/(SICI)1099095X(199805/06)9:3<329::AID-ENV308>3.0.CO;2-9

Voltolina A. and Voltolina P. (1976). Observaciones hidrobiológicas de la Laguna de Punta de Piedras, Isla 
de Margarita: septiembre 1965-diciembre 1966. Mem. Soc. Cienc. Nat. La Salle 36(104), 127-154.

Zamakona A. 1986. Contribución al estudio del intercambio de volúmenes de agua en la Laguna de Punta de Piedras con el medio adyacente. Trabajo de grado TSU. Instituto Universitario de Tecnología del Mar,
Fundación La Salle de Ciencias Naturales, Punta de Piedras, Venezuela, $20 \mathrm{pp}$.

Zimmerman A. and Canuel E. (2002). Sediment geochemical records of eutrophication in the mesohaline Chesapeake Bay. Limnol. Oceanogr. 47(4), 1084-1093. https://doi.org/10.4319/lo.2002.47.4.1084 